\title{
Consumer Trust Analysis of Reviews, Ratings and Facility Information on the Booking Decision Process of Hotel Traveloka
}

\author{
Yanti Murni Sri Marti Pramudena M. Ali Iqbal Dharma Putra Sri Widyastuti
}

\begin{abstract}
In the coming year, it is estimated that holiday activities will continue to be part of the lifestyle of the Indonesian people. Traveloka with unicorn status is present in Indonesia as an online travel agent which in 2014 entered the hotel reservation business. Competition is very tight from competitors, Traveloka continues to strive to provide the best for its consumers. Traveloka provides services in the form of reviews, ratings and hotel facilities. The purpose of this study was to determine the effect of: consumer trust on hotel booking decisions, reviews of hotel booking decisions both directly and through trust, ratings on hotel booking decisions both directly and through trust, facilities on hotel booking decisions both directly and through trust. The increasing competition requires each retailer to strive to maintain and even win the competition between retailers by understanding consumer behavior, for online shopping consumers, as much as possible can be used as input or consideration in online shopping, and of course as a reference for future researchers. The population is an unknown number of consumers who have booked hotels on Traveloka. The sample data of 200 were obtained by purposive sampling using google form to obtain primary data. The research design used explanatory research. Data were analyzed using path analysis, where data quality tests were previously carried out. The results showed that reviews had no significant effect on trust, reviews had no significant effect on hotel booking decisions, rating had a significant effect on trustworthiness, rating had no significant effect on hotel bookings, information on facilities had a significant effect on trust, facilities information had no significant effect on hotel booking decisions. and trust has a significant effect on hotel booking decisions.
\end{abstract}

Keywords: Reviews, rating, facility information, trust, hotel booking decisions.

DOI: $10.7176 / \mathrm{EJBM} / 12-30-04$

Publication date:October $31^{\text {st }} 2020$

\section{INTRODUCTION}

This phenomenon of sa'at society where during the holidays the most popular types of activities are visiting culinary attractions, amusement parks, historical sites, nature tourism and shopping. The majority of users book accommodation considering location and Instagrammable hotels. In the coming years, it is estimated that holiday activities will continue to be part of the lifestyle of the Indonesian people, so that it will increase hotel bookings both offline and online.

The growth of OTA is still unstable, in 2012-2013 seven pure OTAs (Online Travel Agencies) were established in Indonesia, most of which are located in Jakarta (Rosyidi, 2018).

Traveloka is one of the unicorn startups from Indonesia engaged in an online travel agency which at the beginning of its establishment dominated the sales of airline tickets, and in March 2014 Traveloka entered the hotel room reservation business.

With the development of online hotel reservations, Traveloka is facing very tough competition from several competitors such as Booking.com, Agoda, Tiket.com, Pegipegi, Trivago, Hotels.com, air bnb and others. That's why Traveloka must continue to strive to provide the best service for its consumers. 
Table 1

Top Brand Index (TBI) Online Hotel Reservation Site 2015-2019

\begin{tabular}{|c|c|c|c|}
\hline & BRAND & TBI & Keterangan \\
\hline \multirow{5}{*}{$\begin{array}{c}\text { Fase } 2 \\
2015\end{array}$} & Traveloka.com & $60,3 \%$ & TOP \\
\hline & Agoda.com & $10,8 \%$ & TOP \\
\hline & Hotels.com & $8,5 \%$ & \\
\hline & Orbitz.com & $3,7 \%$ & \\
\hline & Booking.com & $2,5 \%$ & \\
\hline \multirow{5}{*}{$\begin{array}{c}\text { Fase } 2 \\
2016\end{array}$} & Traveloka.com & $59,6 \%$ & TOP \\
\hline & Trivago.co.id & $13,5 \%$ & TOP \\
\hline & Agoda.com & $11,6 \%$ & TOP \\
\hline & Pegi-pegi.com & $4,7 \%$ & \\
\hline & Rajakamar.com & $2,0 \%$ & \\
\hline \multirow{5}{*}{$\begin{array}{c}\text { Fase } 2 \\
2017\end{array}$} & Traveloka.com & $59,8 \%$ & TOP \\
\hline & Trivago.co.id & $13,3 \%$ & TOP \\
\hline & Agoda.com & $9,4 \%$ & \\
\hline & Pegi-pegi.com & $3,1 \%$ & \\
\hline & Booking.com & $2,0 \%$ & \\
\hline \multirow{5}{*}{$\begin{array}{c}\text { Fase } 2 \\
2018\end{array}$} & Traveloka.com & $42,0 \%$ & TOP \\
\hline & Trivago.co.id & $13,0 \%$ & TOP \\
\hline & Pegi-pegi.com & $8,6 \%$ & \\
\hline & Misteraladin.com & $6,8 \%$ & \\
\hline & Tiket.com & $4,2 \%$ & \\
\hline \multirow{5}{*}{$\begin{array}{c}\text { Fase } 2 \\
2019\end{array}$} & Traveloka.com & $30,0 \%$ & TOP \\
\hline & Tiket.com & $6,0 \%$ & \\
\hline & Trivago.co.id & $4,9 \%$ & \\
\hline & Agoda.com & $2,7 \%$ & \\
\hline & Pegi-pegi.com & $1,8 \%$ & \\
\hline
\end{tabular}

Source: www.topbrand-award.com

From 2017 to 2019 TBI for Traveloka has always been in the TOP position among other OTAs in Indonesia, but you can see that the TBI value has decreased over time.

Besides the convenience of shopping online, there are many new crimes created, one of which is online fraud.

Online shopping consumer complaints increased sharply. According to data from the Indonesian Consumers Foundation (YLKI), around 642 complaints (16\%) people in 2017 complained about online shopping platform services (e-commerce). The trend of online shopping complaints increased by $16 \%$ from 2016 . Throughout 2018 the trend of online consumer complaints reached 564 complaints throughout 2018. This number has decreased compared to 2017, which was 642 complaints. This results in low consumer confidence in online shopping transactions. Pure (2018)

Another disadvantage of online shopping is that it is difficult to get information about the products / services offered. Several marketplaces provide services in the form of reviews and ratings from consumers who have used services / purchased products that potential consumers can see. Reviews are the opinions of consumers who have made transactions which can be in the form of praise or criticism of the goods / services, while rating is an assessment in the form of rank which is usually symbolized by a star.

Research by Halim (2015), Ismayanti, Suardana and Negara (2015), Sparks, Browning (2011), Almana \& Mirza (2013) concluded that consumer trust has a significant positive effect on hotel bookings, unlike Lien, Huang, Wen (2015), Danish (2019) who concluded that trust has no significant effect on hotel bookings.

Auliya, Umam, Prastiwi (2017), Halim (2015), Singh (2015), Kim, Park, Kim (2017), ChunChan et al (2017), Sparks, Browning (2011) concluded that consumer reviews have a significant positive effect on hotel bookings. , while Zhao et al (2015), Danish (2019), Wang et al (2015) concluded that reviews had no significant effect on hotel bookings.

Halim (2015), Wahyudi, Rinuastuti, Sarmo (2019), Gavilan, Martinez, Avello (2017), reviews have a positive effect on trust, while Farki, Baihaqi (2016), Zhao et al (2015), Danish (2019) say that no significant effect of reviews on trust.

Research from Auliya, Umam, CHuChan et al (2017), Singh (2015), Kim, Park, Kim (2017), Sparks, Browning (2011) concluded that ratings have a positive effect on hotel bookings, while Zhao et al (2015), Danish (2019), Wang et al (2015) concluded that there was no significant effect of rating on hotel bookings.

Halim (2015), Wahyudi, Rinuastuti, Sarmo (2019), Gavilan, Martinez, Avello (2017) concluded that rating has a positive effect on trust, but Farki, Baihaqi (2016), Zhao et al. (2015) concluded that rating has no significant 
effect on trust.

Based on the results of previous research above, researchers are interested in knowing further whether reviews, ratings and facility information have an effect on Traveloka hotel bookings either directly or through consumer trust as an intervention. Problem Formulation

For this research, several problems can be formulated:

1. How does consumer trust affect hotel booking decisions at Traveloka?

2. How do reviews influence Traveloka hotel booking decisions, both directly and through consumer trust.

3. How does rating affect Traveloka hotel booking decisions, both directly and through consumer trust.

4. How does facility information affect Traveloka hotel booking decisions, both directly and through consumer trust.

\section{LITERATURE STUDY}

\section{E-Commerce}

Kotler and Keller (2016: 508), "Online Marketing is efforts to market products and services and build customer relationships over the Internet". Then Kotler and Keller (2016: 508) also explain, "the internet is a vast public web of computer networks that connects users of all types around the world to each other and an amazingly large information repository". E-commerce is an electronic commerce medium that has certain characteristics or traits (Laudon, \& Laudon, 2014).

Online Hotel Booking Decisions

Halim (2015), online hotel bookings are bookings made by customers directly. Consumers will try to find information related to the quality of hotel services through reviews from consumers who have booked the hotel online. The dimensions of hotel bookings used are Gozzali \& Kristanti (2013), Popularity and Technology, Reliability, Ease, Speed, Information, Prices and Rewards.

Reviews and Ratings

Before consumers buy products / services online shopping, consumers are used to looking for information that can be searched in various ways. Mo et al (2015).

Review

Almana and Mirza (2013), online consumer reviews are used as a means for consumers to find information that will influence purchasing decisions. Online consumer review, a form of electronic word of mouth that can be said as a new marketing communication that can influence and play a role in the purchasing decision process (Sutanto and Aprianingsih, 2016). Added by Lee \& Shin (2014), a review is a person's direct opinion and not an advertisement.

It can be concluded that the reviews in this study are the consumer experience in booking hotels on Traveloka.

Rating

Rating is the opinion of customers on a certain scale and is applied in online stores by giving stars. The more stars you give, the better your sales ranking is. Lackermair et al (2013). Rating is another type of opinion given by many people and is an average evaluation of buyers-rating providers of different features of the product or service seller, Filieri (2014), and represents consumer opinion on a specific scale (Lackermair et al, 2013). The number of stars can be associated with the quality of an item sold online (Mukhopadhyay \& Chung, 2015)

Reviews and ratings in this study use dimensions, Metsger (2007): Credible, consisting of: Trustworthy, Honest (Honest), Expertise (Expert), consisting of: Professional, Useful (Useful) Likely: Likely, Interesting, Possibility to buy from the website (Likely Buy From This Website)

\section{Hotel Facility Information}

Information.

Krismaji $(2015 ; 14)$, Information is data that has been organized and has uses and benefits. Likewise Romney and Steinbart (2015: 4), information is data that has been managed and processed to provide meaning and improve the decision-making process.

Amenities

Facilities are the environments in which services are delivered and where companies and their consumers interact, as well as any tangible consumer that facilitates the performance or communication of services.

It can be concluded that hotel facility information is information about the hotel and its supporting facilities. Sulastiyono $(2006 ; 48)$, the facilities in a hotel are bedrooms with all the equipment, restaurant / caffe with its supporters, additional facilities (sports and entertainment facilities), and others.

Consumer Trust

Trust is the willingness of the company to rely on business partners. Kotler and Keller (2016), Indicators of Trust; Seriousness / sincerity (Benevolence), how much a person believes in the seller to behave well to consumers. Ability,

Ability is an up-to-date assessment of what that one can do. Integrity. Integrity is how much someone believes in the honesty of the seller to maintain and fulfill the agreements that have been made to consumers. Willingness to 
depend. Willingness to depend is the willingness of consumers to depend on the seller in the form of accepting risks or negative consequences that may occur.

\section{HYPOTHESIS}

H1: There is an effect of consumer confidence on hotel booking decisions Traveloka.

$\mathrm{H} 2$ : There is an effect of reviews on Traveloka hotel booking decisions

H3: There is a rating effect on Traveloka hotel booking decisions

H4: There is an effect of facility information on Traveloka hotel booking decisions

H5: There is an effect of reviews on consumer confidence in bookin hotels Traveloka.

H6: There is a rating effect on consumer confidence in Traveloka hotel bookings

H7: There is an effect of facility information on booking consumer confidence Traveloka hotel

\section{RESEARCH METHOD}

Variable

There are 3 variables in the study: independent variables, namely; Reviews (X1), Rating (X2) and Facility Information (X3). Dependent Variable: Booking hotel (Y) and Intervening variable: Trust (Z).

Variable Measurement

Measurement of variables using a Likert scale, where the variables to be measured are translated into variable indicators, with a scale of 1-5.

\section{Population and Sample}

Population

The population in this study are all consumers who have purchased Traveloka hotel rooms where the number is unknown.

Sample

Referring to Roscoe in Sugiyono (2017: 90-91), the proper sample size in the study is between 30 to 500 . So the sample size used in this study was 200 respondents. Meanwhile, the sampling technique uses purposive sampling (Sugiono, 2017: 85), namely consumers who have made hotel bookings at Traveloka.

Data collection technique

This study uses primary data as a data source, data is collected using google form.

Data analysis method

This study uses data analysis methods using SmartPLS version 2.3.9 software which runs on computer media.

\section{RESEARCH RESULTS AND DISCUSSION}

\section{A. Results}

1. Characteristics of Respondents

a. Based on Gender

Table 6.1

Characteristics of Respondents Based on Gender

\begin{tabular}{l|c|c|}
\hline \multicolumn{1}{c}{ Gender } & Frequency & Percentage (\%) \\
\hline Male & 83 & 41,5 \\
\hline Famele & 117 & 58,5 \\
\hline Total & $\mathbf{2 0 0}$ & $\mathbf{1 0 0}$ \\
\hline
\end{tabular}

Source: Results of Data Processing with the SPSS 21 Program

Based on Table 6.1 it can be seen that the respondents in the study were male, namely 83 people $(41.5 \%)$, and the rest were female, namely 117 people $(58.5 \% \%)$. This shows that those who book hotels on Traveloka are more dominated by women than men.

b. Description of Respondents by Age

Table 6.2

Characteristics of Respondents by Age

\begin{tabular}{|c|c|c|}
\hline Age & Frequency & Percentage (\%) \\
\hline$<20$ Years & 9 & 4,5 \\
\hline 21-35 Years & 57 & 28,5 \\
\hline 36-50 Years & 113 & 56,5 \\
\hline 51-60 Years & 11 & 5,5 \\
\hline$>60$ Years & 10 & 5,0 \\
\hline Total & 200 & 100 \\
\hline
\end{tabular}

Source: Results of Data Processing with the SPSS 21 Program

From the results of the table of respondent characteristics based on the above age, it can be concluded that 
the majority of those who book hotels on Traveloka are aged between 36-50 years because at this age it is located in the millennial age who are already income and respondents in this age range are more receptive and want to try new technology Through the internet.

Respondents' Descriptions by Occupation

Table 6.3

Characteristics of Respondents by Occupation

\begin{tabular}{|c|c|c|}
\hline \multicolumn{1}{c}{ Education } & Frequency & Percentage (\%) \\
\hline \multicolumn{1}{c}{ ASN } & 9 & 4,5 \\
\hline Private & 115 & 57,5 \\
\hline Student & 51 & 25,5 \\
\hline Housewife & 7 & 3,5 \\
\hline Others & 18 & 9,0 \\
\hline Total & 200 & 100 \\
\hline
\end{tabular}

From the results of the table of respondent characteristics based on the work above, it can be concluded that the majority of those who book hotels at Traveloka are those who work as private companies because at this age it is located at the already income age and also respondents in this age range most of them do not have time to buy offline travel. .

B. Characteristics of Respondents Based on Domicile

Table 6.4

Characteristics of Respondents Based on Domicile

\begin{tabular}{l|c|c|}
\hline \multicolumn{1}{c}{ Dimensional } & Frequwncy & Persentase (\%) \\
\hline Jabodetabek & 154 & 77 \\
\hline Others & 46 & 23 \\
\hline Total & $\mathbf{2 0 0}$ & $\mathbf{1 0 0}$ \\
\hline
\end{tabular}

Source: Results of Data Processing with the SPSS 21 Program

Based on Table 6.4, it can be seen that the respondents in this study who are domiciled in Jabodetabek are 154 people $(77 \%)$, and the remaining $23 \%$ are outside Jabodetabek.

2. Cronbach Alpha

a. Reliability test with composite reliability A variable can be declared reliable or meets Cronbach alpha if it has a Cronbach alpha value $>0.7$. The following is the cronbach alpha value of each variable:

Table 6.11

Cronbach's Alpha

\begin{tabular}{|c|c|}
\hline Variable & Cronbach's Alpha \\
\hline Reviews of & 0.907 \\
\hline Rating & 0.906 \\
\hline Facility Information & 0.896 \\
\hline Trust & 0.937 \\
\hline Hotel Booking Decisions & 0.906 \\
\hline
\end{tabular}

Source: Primary data (processed)

Based on the data presentation above in table 6.11, it can be seen that the Cronbach alpha value of each research variable is $>0.7$. Thus these results indicate that each research variable has met the requirements for the Cronbach alpha value, so it can be concluded that all variables have a high level of reliability.

b. Model Feasibility Test (Goodness of Fit)

Based on data processing that has been done with

using the smartPLS 3.0 program, the R-Square value is obtained as follows:

Table 6.12

R-Square Value

\begin{tabular}{|c|c|}
\hline Variabel & Nilai $R$-Square \\
\hline Trust & 0.651 \\
\hline Hotel Booking Decisions & 0.614 \\
\hline
\end{tabular}

Source: Primary data (processed)

Based on table 6.12 above, it can be seen that the R-Square value for the trust variable is 0.651 . The acquisition of this value explains that the percentage of trustworthiness can be explained by reviews, ratings, and facility information of $65.1 \%$. Then for the R-Square value obtained the hotel booking decision variable is 0.614 . This value explains that the hotel booking decision can be explained by reviews, ratings, facility information, and trust 
by $61.4 \%$

The goodness of fit assessment is known from the Q-Square value. The value of Q-Square has the same meaning as coefficient determination (R-Square) in regression analysis, where the higher the Q-Square, the model can be said to be better or more fit with the data. The results of the calculation of the Q-Square value are as follows:

$$
\begin{aligned}
& \text { Q-Square }=1-[(1-\mathrm{R} 21) \times(1-\mathrm{R} 22)] \\
& \quad=1-[(1-0.651) \times(1-0.614)] \\
& =1-(0.349 \times 0.386) \\
& =1-0.135 \\
& =0.865
\end{aligned}
$$

Based on the results of the above calculations, the Q-Square value is 0.865 . This shows the great diversity of research data that can be explained by the research model is $86.5 \%$, while the remaining $13.5 \%$ is explained by other factors that are outside of this research model. Thus, from these results, this research model can be stated as having a good goodness of fit.

3. Hypothesis Testing

Based on the data processing that has been done, the results can be used to answer the hypothesis in this study. Hypothesis testing in this study was carried out by looking at the T-Statistics value and the P-Values value. The research hypothesis can be declared accepted if the T-Statistics value is $>1.96$ and the P-Values $<0.05$. In the following are the results of this research hypothesis:

\section{Direct Effect}

Table 6.13

\begin{tabular}{|c|c|c|c|c|}
\hline Hipotesis & Pengaruh & T-Statistics & P-Values & Hasil \\
\hline $\mathrm{H}_{1}$ & Trust => Booking Hote Decision & 6.841 & 0.000 & Received \\
\hline $\mathrm{H}_{2}$ & Review => Booking Hote Decisions & 1.453 & 0.147 & Rejected \\
\hline $\mathrm{H}_{3}$ & Rating => Hotel Booking Decision & 0.915 & 0.361 & Rejected \\
\hline $\mathrm{H}_{4}$ & Facility Information => Hotel Booking Decision & 0.267 & 0.789 & Rejected \\
\hline $\mathrm{H}_{5}$ & Review => Trust & 1.008 & 0.314 & Rejected \\
\hline $\mathrm{H}_{6}$ & Rating => Trustworthiness & 2.596 & 0.010 & Received \\
\hline $\mathrm{H}_{7}$ & Facility Information => Trust & 5.510 & 0.000 & Received \\
\hline
\end{tabular}

Source: Primary data (processed)

Based on the data presented in table 6.13 above, the direct effect of the relationship between variables in the table above can be explained as follows:

1. The $\mathrm{T}$ value of the trust variable on the hotel booking decision is 6,841 with a significance value of 0,000 . because the value of $\mathrm{T}$ count $>1.96$ and a significance value of $<0.05$, this indicates that there is a significant positive influence between trust in hotel booking decisions or the hypothesis is accepted.

2. The $\mathrm{T}$ value of the variable Reviews of the Booking Hotel Decision is 1.453 with a significance value of 0.147 . because the value of $\mathrm{T}$ count $<1.96$ and the value of significance $>0.05$, this indicates that there is no significant effect between reviews on hotel booking decisions or the hypothesis is rejected.

3. The $\mathrm{T}$ value of the Rating variable against the Hotel Booking Decision is 0.915 with a significance value of 0.361 . because the value of $T$ count $<1.96$ and the significance value $>0.05$, this indicates that there is no influence between the rating on the hotel booking decision or the hypothesis is rejected.

4. The $\mathrm{T}$ value of the Facility Information variable on the Hotel Booking Decision is 0.267 with a significance value of 0.789 . because the value of $T$ count $<1.96$ and the value of significance $>0.05$, this indicates that there is no influence between facility information on hotel booking decisions or the hypothesis is rejected.

5. The $\mathrm{T}$ value of the variable Review of Trustworthiness is 1,008 with a significance value of 0.314 . because the value of $T$ count $<1.96$ and the value of significance $>0.05$, this indicates that there is no significant effect between reviews on trust or the hypothesis is rejected.

6. The $T$ value of the Rating variable on Trust is 2.595 with a significance value of 0.010 . because the value of $T$ count $>1.96$ and a significance value of $<0.05$, this indicates that there is a positive and significant influence between the rating on trust or the hypothesis is accepted.

7. The $T$ value of the Facility Information variable on Trust is 5.510 with a significance value of 0.000 . because the value of $\mathrm{T}$ count $>1.96$ and a significance value of $<0.05$, this indicates that there is a significant positive effect between facility information on trust or the hypothesis is accepted.

b. Indirect Effect 
Table 6.14

T-statistics and P-Values

\begin{tabular}{|c|c|c|c|c|}
\hline Hypothesis & Influence & T-Statistics & P-Values & Results \\
\hline $\mathrm{H}_{1}$ & Review => Hotel Booking Decision & 0.980 & 0.328 & Rejected \\
\hline $\mathrm{H}_{2}$ & Rating => Hotel Booking Decision & 2.462 & 0.014 & Accepted \\
\hline $\mathrm{H}_{3}$ & Facility Information => Hotel Booking Decision & 4.131 & 0.000 & Accepted \\
\hline
\end{tabular}

Source: Primary data (processed)

Based on the data presented in table 5.9 above, the indirect effect of the relationship between variables in the table above can be explained as follows:

1. The $\mathrm{T}$ value of the variable Reviews of the Booking Hotel Decision is 0.980 with a significance value of 0.328 . because the value of $\mathrm{T}$ count $<1.96$ and the value of significance $>0.05$, this indicates that there is no indirect effect between reviews on hotel booking decisions or the hypothesis is rejected.

2. The $\mathrm{T}$ value of the Rating variable against the Booking Hotel Decision is 2.462 with a significance value of 0.014 . because the value of $T$ count $>1.96$ and a significance value of $<0.05$, this indicates that there is an indirect influence between the rating on the hotel booking decision or the hypothesis is accepted.

3. The $\mathrm{T}$ value of the Facility Information variable on the Hotel Booking Decision is 4.131 with a significance value of 0.000 . because the value of $T$ count $>1.96$ and a significance value of $<0.05$, this indicates that there is an indirect influence between facility information on hotel booking decisions or the hypothesis is accepted.

B. Discussion

Based on hypothesis testing that has been carried out using the smartPLS 3.0 program on 200 samples who have made hotel bookings at Traveloka.

The Effect of Trust on Traveloka Hotel Booking Decisions

Based on the research results, it is known that trust has a positive and significant effect on hotel booking decisions, so the first hypothesis (H1): there is an effect of consumer trust on hotel booking decisions.

Traveloka is acceptable, which means that consumer confidence is increasing, so the decision to book Traveloka hotels will also increase.

The results of this study are supported by research conducted by Halim (2015), Ismayanti, Suardana, Negara (2015), Sparks, Browning (2011) which concludes that consumer trust has a significant positive effect on Traveloka hotel booking decisions.

b. The Effect of Reviews on Traveloka Hotel Bookings

Based on the research results, it is known that reviews have a positive and insignificant effect on Traveloka hotel bookings, so the second hypothesis (H2): there is an effect of reviews on Traveloka hotel booking decisions being rejected, which means that reviews are increasing, the review decision will increase, so the hotel booking decision will also increase. however the increase is not significant.

The results of this study are supported by Zhao et al (2015), Danish (2019) and Wang et al (2015) who concluded that reviews have no significant effect on hotel bookings.

c. The Effect of Rating on Traveloka Hotel Booking Decisions

Based on the results of the study, it is known that the rating has a positive and insignificant effect on Traveloka hotel bookings, so the third hypothesis (H3): there is a rating effect on Traveloka hotel booking decisions being rejected, which means that the rating increases, the decision to book hotels on Traveloka will also increase but the increase will not significant.

The results of this study are supported by Zhao et al (2015), Danish (2019), Wang et al (2015) who concluded that rating does not have a significant effect on hotel bookings.

The Effect of Facility Information on Traveloka Hotel Booking Decisions

Based on the results of the study, it is known that facility information has a positive and significant effect on hotel booking decisions, so the fourth hypothesis (H4): there is an effect of facility information on hotel booking decisions at Traveloka which is rejected, which means that the information on facilities provided is rarely considered by Traveloka consumers or is not a consideration to decide to buy tickets on Traveloka.

The Effect of Reviews on the Trust of Traveloka hotel consumers

Based on the research results it is known that reviews have a positive and insignificant effect on trust, so the second hypothesis (H5): there is an effect of reviews on Traveloka hotel booking decisions being rejected, which means that reviews are increasing, so trust will also increase but the increase is not significant. The results of this study are supported by research conducted by Farki, Baihaqi (2016), Zhao et al (2015), Danish (2019), Wang et al (2015) who concluded that reviews have no significant effect on hotel consumer confidence.

d. The Effect of Rating on the Trust of Traveloka hotel consumers

Based on the results of the study, it is known that rating has a positive and significant effect on trust, so the fourth hypothesis (H6): there is an acceptable rating effect on trust, which means that the higher the rating, the higher the level of trust. 
The results of this study are supported by research conducted by Halim (2015), Wahyudi, Rinuastuti, Sarmo (2019), Gavilan, Martinez, Avello (2017) which concluded that rating has a significant positive effect on consumer trust. The Effect of Facility Information on the Trustworthiness of Traveloka hotels

Based on the research results, it is known that facility information has a positive and very significant effect on trust, so the fourth hypothesis (H7): there is an effect of facility information on Traveloka consumer confidence, which means that facility information is clearer and attracts information, the level of trust will also increase. Halim concluded that facility information has a significant effect on consumer confidence.

\section{CONCLUSIONS AND SUGGESTIONS}

1. Conclusions

In this research on hotel bookings at Traveloka, the following conclusions can be drawn.

1. Trust has a positive and significant effect on hotel booking decisions, meaning that consumer confidence is increasing, so the booking decision for Traeloka hotels will also increase.

2. Reviews have a positive and insignificant effect on hotel booking decisions, meaning that Reviews are increasing, so Traveloka hotel booking decisions will also increase, but the increase is not significant.

3. Ratings have a positive and insignificant effect on hotel booking decisions, meaning that the rating increases, the Traveloka hotel booking decision will also increase, but the increase is not significant

4. Information on positive facilities and insignificant towards Traveloka hotel booking decisions. If the information on the facilities provided is more complete, clear and but not always a consideration for consumers in deciding to book a Traveloka hotel.

5. Reviews have a positive and insignificant effect on consumer confidence, meaning that reviews are increasing, consumer confidence will also increase, but the increase is not significant.

6. Rating has a positive and significant effect on consumer confidence, meaning that the higher the rating, the level of consumer confidence will also increase.

7. Information on facilities is positive and has a very significant effect on consumer confidence, meaning that facility information is clearer and more interesting, so the level of consumer confidence will also increase.

\section{Suggestions}

Respondents still doubt the veracity of the reviews that are presented as true to their experiences. Therefore it is recommended that traveloka filter out the correct reviews, so that the reviews that are presented can generate trust which will influence consumers in deciding to book a hotel.

Likewise, the rating given as an experience to stay, even though it is trustworthy, can influence consumers to book hotels.

Respondents in this study were also less interested in the information presented on the available hotel facilities as a basis for making decisions to book hotels.

\section{REFERENCES}

Almana, A.M, Mirza, A.A .2013. The Impact of Electronic Word of Mouth on Consumers Purchasing decisions. International journal of ComputerScience, doi:10.5120/14145-2286

Auliya, Z.F, Umam M R K, Prastiwi S.K. 2017. Online Costumer Reviews (OTR) dab Rating: Kekuatan Baru pada Pemasaran Online di Indonesia. EBBANK, Vol.8, No.1, Juni 2017, Halaman : 89-98, LP3M STIEBBANK,. ISSN (online): 2442-4439, ISSN (print) : 2087 -1406

ChuChan I, Lam LW, Chow CWC, Fong LHN, Roblaw. September 2017. The effect of online reviews on hotel booking intention: The role of reader-reviewer similarity. International Journal of Hospitality Management, Volume 66, Pages 54-65

Danish RQ.March 2019, Impact of Online Consumer Reviews on Hotel Booking Intentions: The Case of Pakistan, European Scientific Hournal, Vol.15, No.7, ISSN: 1857-7881 (Print), e-ISSN 1857-7431, P: 144-159.

Filieri,R.2014. What makes online reviews helpful? A diagnosticity-adoptionframework to explain informational and normative influences in e-WOM. Journal of Business Research, 68(6), pp.1261-1270.

Gavilan,D, Martinez,G, Avello,M.2017. The influence of online ratings and reviews on hotel booking consideration, ResearchGate iOS App, Article (PDF Available) in Tourism Management 66(66):53$61 \cdot$ October 2017.

DOI: $10.1016 /$ j.tourman.2017.10.018

Gozzali, S \& Kristanti, M.2013. Faktor-Faktor Yang Mendorong Masyarakat Surabaya Dalam Melakukan Reservasi Hotel Secara Online. Manajemen Perhotelan Universitas Kristen Petra, Surabaya, Indonesia 